\title{
The Future and Challenges of LNG
}

\author{
E.M. Amarfio*, E.A. Ntiamoah, B.A. Bediako, O. Brobbey \\ University of Mines and Technology, Tarkwa, Ghana
}

*Corresponding Author: E.M. Amarfio, University of Mines and Technology, Tarkwa, Ghana

\begin{abstract}
Global demand for energy keeps increasing from day to day because of economic growth and industrialisation among others. Fossil fuels such as coal, petroleum and natural gas account for the largest source of energy supply. Nevertheless, the burning of these fossil fuels to produce energy comes along with emission of greenhouse gases such as carbon dioxide, nitrous oxide and sulphur hexafluoride, which pollute the environment. Natural gas is considered as a clean energy source as compared to coal and petroleum because it emits about 50 to 60 percent less carbon dioxide, thus, it has less adverse effects on the environment than that of coal and petroleum. This study seeks to identify the drivers of petroleum energy, the indicators that make Liquefied Natural Gas (LNG) the future energy resource as well as the challenges of LNG. Microsoft Excel was used to statistically analyse secondary data from multiple sources including BP statistics, Statista, US Energy Information Administration (EIA), among others. The drivers of petroleum identified were population growth, electrical power and transportation. Increase in proved gas reserves, LNG global trade, liquefaction plant capacity, LNG vessels and enforcement of new and existing regulations were identified as the indicators that make LNG the future energy resource. Key challenges that might disturb these drivers include are not limited to the following: delay in permitting the approval and fiscal regimes of LNG projects; project and equity financing challenges; challenging weather conditions and the fact that LNG cannot be burnt directly in an engine.
\end{abstract}

Keywords: Liquefied Natural Gas (LNG), Global Demand, Green House Gases, Clean Energy, Proved Gas Reserves.

\section{INTRODUCTION}

Global demand for energy keeps increasing from day to day because of economic growth developments and industrialization, among several other factors. Global energy demand increased from $1.6 \%$ in 2016 to $2.2 \%$ by the end of 2017 (Anon, 2018a). The sources of energy include fossil fuels (coal, petroleum, natural gas), nuclear power and renewable energy (solar, wind, geothermal, bioenergy).

Petroleum remains the largest source of energy. Petroleum, which is converted into rich energy fuels such as gasoline, diesel, Liquefied Petroleum Gas (LPG) and other fuel oils as well as natural gas is of high global demand as compared to the other sources of energy. The combustion of these fossil fuels (coal, petroleum and natural gas) to produce energy comes along with the emission of greenhouse gases (carbon dioxide, water vapour, chlorofluorocarbons, hydrofluorocarbons, sulphur hexafluoride, perfluorocarbons and many others) which tend to pollute the environment and cause global warming. Larger quantities of carbon emissions are produced by coal and petroleum as compared to natural gas emissions and this large quantity tends to trap heat in the atmosphere and cause climatic change (Denchak, 2018).

Natural gas emits about 50 to 60 percent less carbon dioxide than coal and petroleum do when combusted, and as such, is considered as a clean energy source. The present consensus in the world energy sector is that natural gas will be the best choice of fuel in the future (Kho, 2005).

Clean energy is a kind of energy considered to have less adverse effects on the environment (Denchak, 2018). Such energy has very low or no carbon dioxide emissions to the environment. Non-renewable energy, specifically natural gas and renewable energy such as solar, wind power and geothermal energy, are classified as clean energy. Studies show that the future demand for energy is going to shift towards clean energy. Most of petroleum energy products are not clean and will eventually fall out simply because most of them do not measure up to the crucial requirements for a reliable energy supply (Kho, 2005). Liquefied Natural Gas will stand out as one of the energy sources of choice among the others. 
This project seeks to study and analyse the future indicators and challenges of liquefied natural gas as one of the clean energy sources that will be leading the global energy demand. The focus of the work is on the future and challenges of LNG.

\section{MeTHOD USED}

\subsection{Data Acquisition}

Secondary data on some factors that drive petroleum energy, as well as those that indicate LNG to be the future choice of energy, especially world population, was obtained from United Nations, Department of Economic and Social Affairs, Population Division. Data on global energy, global electricity consumption, liquefaction plants and floating regasification vessels were obtained from several sources including BP statistics, Statista, US Energy Information Administration (EIA) and International Gas Union (IGU). Table 1 shows collected data on some variables and their corresponding sample period.

Table1. Variables and their Corresponding Sample Period

\begin{tabular}{|c|c|}
\hline Variable & Sample Period \\
\hline World population & $2015-2018$ \\
\hline Worldwide electricity consumption (billion kilowatt hours) & $2012-2015$ \\
\hline Transportation energy consumption (trillion British thermal unit) & $2014-2017$ \\
\hline Energy consumption by fuel type (million tonnes of oil equivalent) & $2015-2040$ \\
\hline Global proved gas reserves (trillion cubic metres) & $2015-2017$ \\
\hline LNG vessels & $2016-2017$ \\
\hline Global LNG traded volume (million tonnes) & $2015-2018$ \\
\hline Liquefaction Plants Capacity (million tonnes per annum) & $2015-2018$ \\
\hline
\end{tabular}

\section{RESULTS AND DISCUSSION}

In this section, statistical data on LNG and its implications are the bases for our discussion.

\subsection{Drivers of Petroleum Energy}

\subsubsection{Population Growth}

Population growth is one of the main drivers of petroleum energy demand in the world. Figure 1 shows the world population from 2015 to 2018.

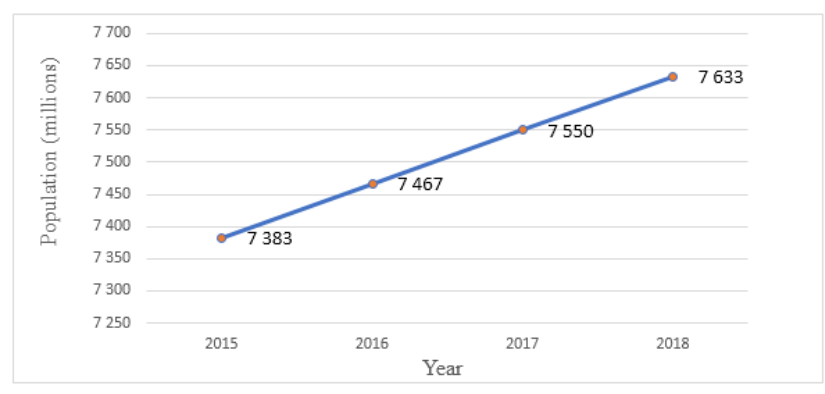

Figure1. World Population from 2015 to 2018

From Figure 1, world population increased gradually as the years advanced. The population increased from 7.3 billion in 2015 to 7.4 billion in 2016. This further increased to 7.5 billion in 2017 and 7.6 billion in 2018. The increase in population is due to poor family planning, improvement in public health and increase in food production and distribution (Kinder, 1998). According to Sokolov et al. (2017), this considerable increase in population affects global energy demand (mostly petroleum energy) in the long term as urban population in developing countries continuously grow, and this induces an increase in energy consumption per capita as household income grows and energy infrastructure is readily available.

\subsubsection{Electrical Power}

Electricity is also another major driver of petroleum energy. Electric power generators could run on coal, natural gas or diesel. Nonetheless, electrical power could also be generated using nuclear or renewable sources. Figure 2 shows global electricity consumption from 2012 to 2015 in billion kilowatt hours. 


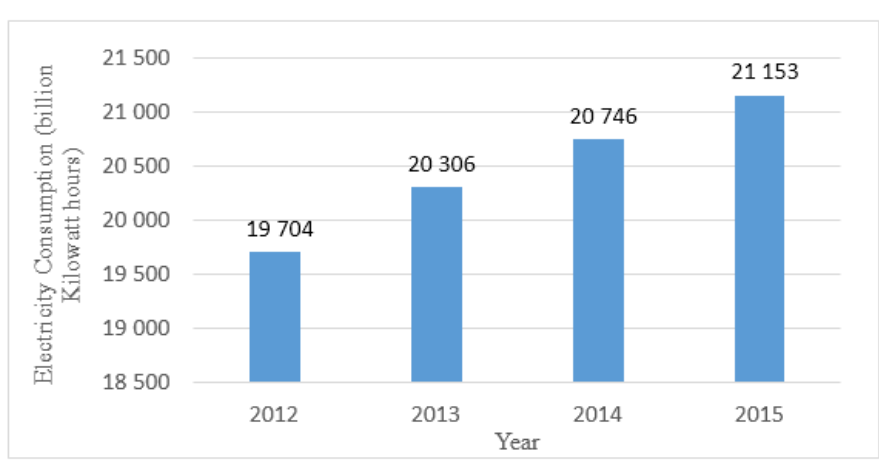

Figure2. Global Electricity Consumption

From Figure 2, global electricity consumption increased as the years continuously advanced from 2012 to 2015. It increased from 19704 billion kilowatt hours in 2012 to 20306 billion kilowatt hours in 2013. It further increased to 20746 billion kilowatt hours and 21153 billion kilowatt hours in 2014 and 2015 respectively. This growth in electricity consumption can be attributed to weather conditions because of the increasing demand for air-conditioning during summer and the increasing call for heating during winter. Again, the growth in electricity consumption was due to industrial expansion, urbanization, as well as increase in residential energy demand particularly in developing economies such as China and India (Sokolov et al., 2017).

\subsubsection{Transportation}

Transportation is another key driver of petroleum energy in the world. Road transport by vehicles, shipping, aviation and pipeline transport make a lot of use of petroleum energy. Table 2 shows the distribution of transportation energy consumption by source.

Table2. Distribution of Transportation Energy Consumption by Source

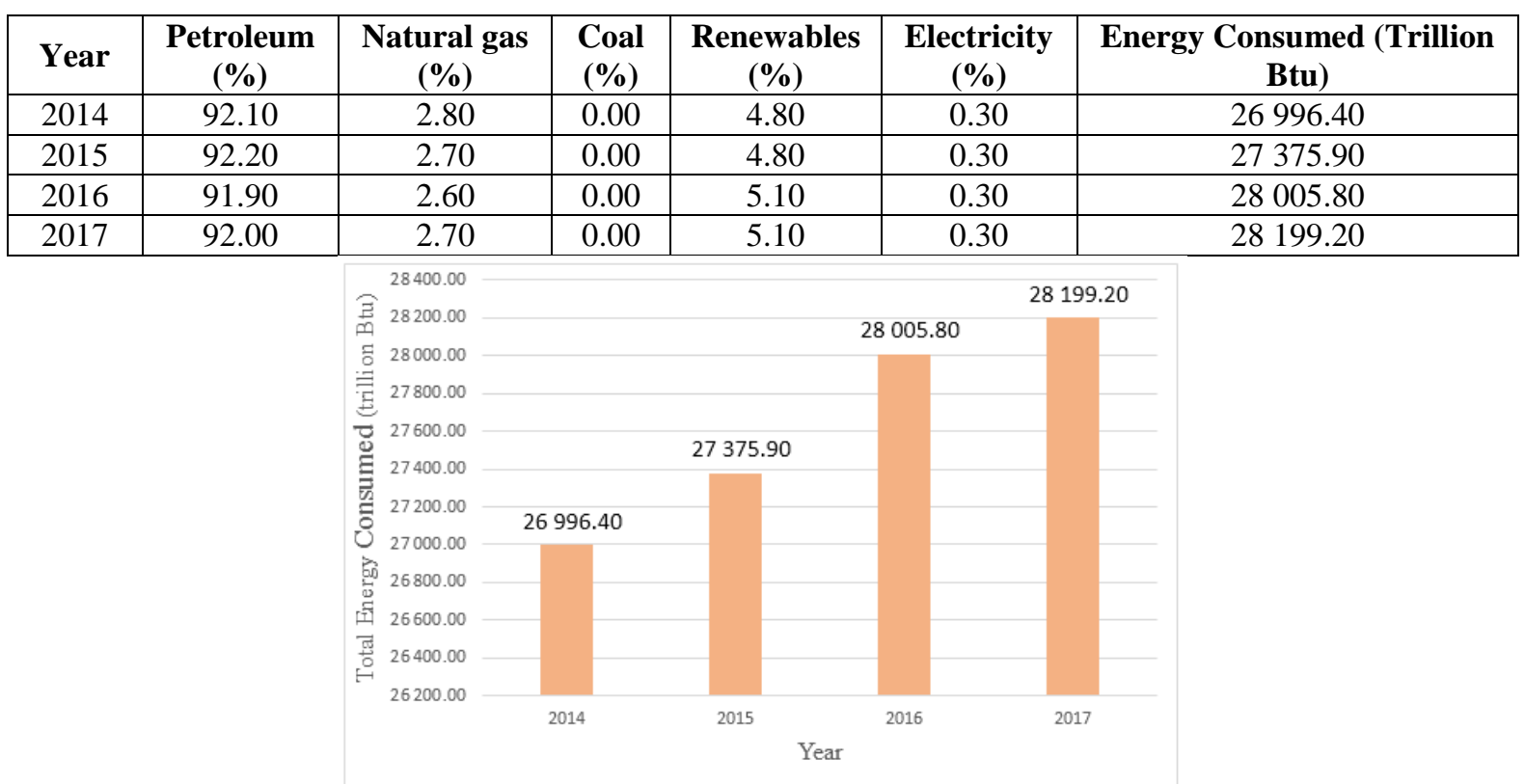

Figure3. Global Energy Consumption by Transportation from 2014 to 2017

From Figure 3, global energy consumption by transportation increased gradually from 26996.4 trillion Btu in 2014 to 27375.90 trillion Btu in 2015. This further increased to 28005.80 and 28199.20 trillion Btu in 2016 and 2017 respectively. This increase in energy consumption is a result of the rapid development in the transportation sector, be it waterway transport, air lift, rails or road transport (Song et al., 2014). Increase in energy consumption by transport is also attributed to several factors including: energy spent in manufacturing and recycling of vehicles, aircrafts and ships; energy used to provide momentum to vehicles; aircrafts or ships by fuels; and the substantial amount of energy used in construction of infrastructure such as roads, railways, bridges and airports. Steady growth in miles travelled drives fuel consumption by vehicles, aircrafts and trains and this is mostly powered by petroleum as seen above in Table 2. Most transportation modes depend on an internal combustion 
engine which could be diesel engines or gas turbines. Aside from railways which usually use electric power, ships and trucks engines are adapted to diesel engines and jet engines are adapted to gas turbine. All the same, transportation is almost completely reliant on petroleum (Rodrigue, 2017).

\subsection{Indicators that Make LNG the Future Energy}

Fossil fuels (coal, natural gas, oil) accounts for a greater portion of global energy mix as compared to nuclear energy, hydro-electric and renewables as shown in Figure 4, right from the past (2016-2017) into the future (2030-2040) as estimates show. Figure 5 shows the energy consumption and growth rate of oil, natural gas and coal.

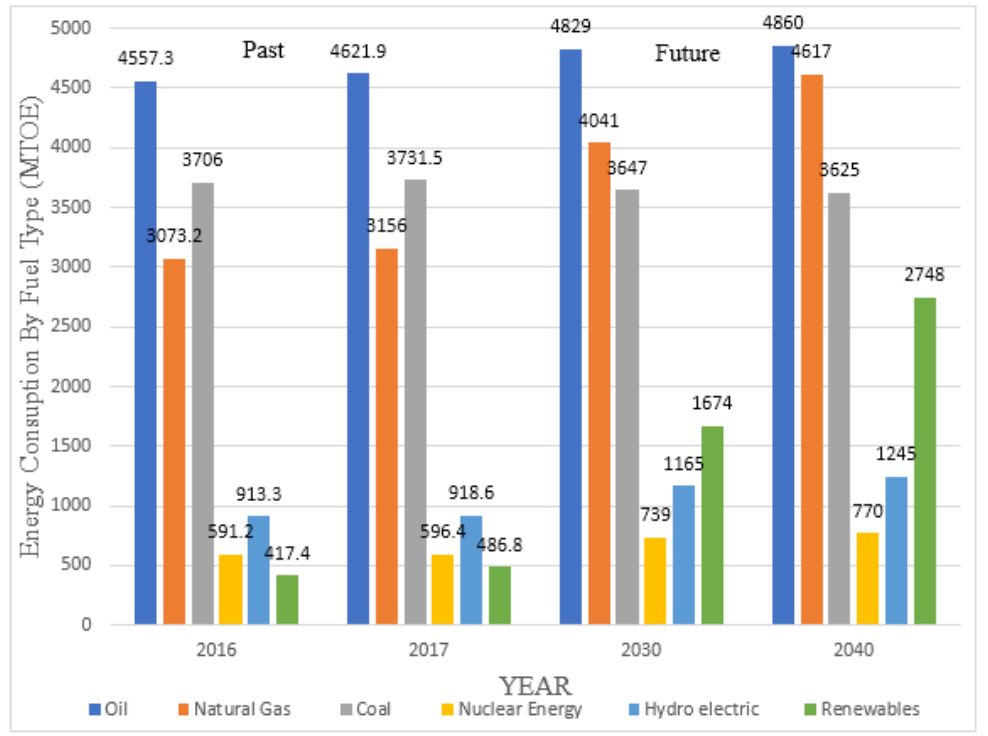

Figure4. Global Primary Energy Consumption by Fuel

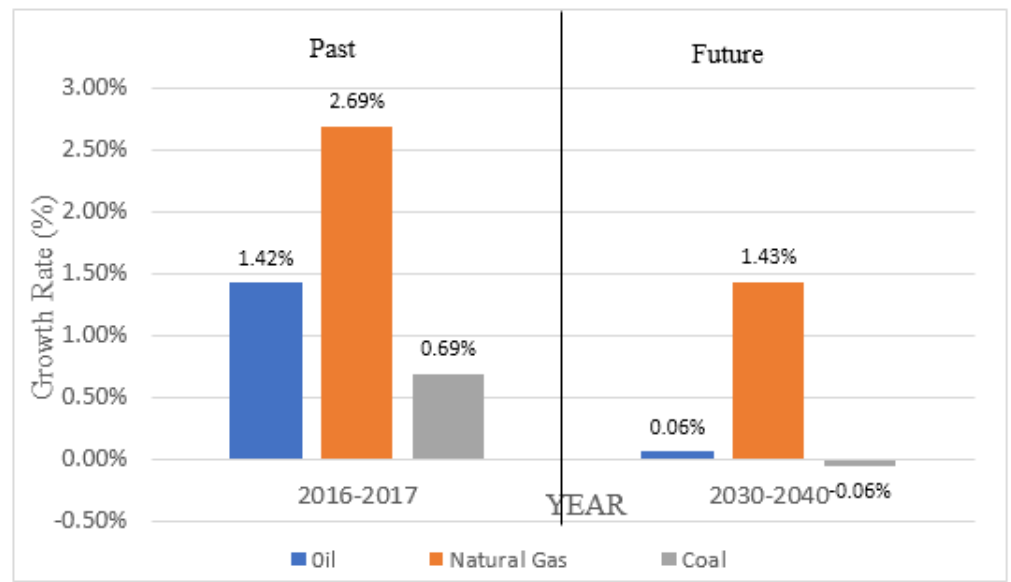

Figure5. Growth Rate in Global Energy Consumption of Oil, Natural Gas and Coal

From Figure 5, the growth rates in energy consumption from 2016 to 2017 recorded were positive $1.42 \%$, positive $2.70 \%$ and positive $0.69 \%$ for oil, natural gas and coal respectively. Estimates show a similar trend in increase in growth rate for natural gas and oil from 2030 to 2040 but a decrease in growth rate for coal. Except for coal experiencing a drastic decrease in growth rate in the future (2030 - 2040) as shown in Figure 5, there was an increase in all sources from the past into the future as estimates show. Nonetheless, natural gas had a higher absolute increase of positive $2.70 \%$ representing 82.8 Million Tonnes of Oil Equivalent (MTOE) increase in demand as compared to positive $1.42 \%$ oil and positive $0.69 \%$ coal in the past $(2016$ - 2017). Estimates for the future $(2030-2040)$ also show a higher increase of positive $1.43 \%$ growth rate of natural gas as compared to positive $0.06 \%$ increase of oil and $0.06 \%$ decrease for coal. This increase in growth rate shows a higher demand for natural gas in the future as compared to the other fossil fuels. Natural gas in a form of liquified natural gas (LNG) will be the only fossil fuel that will see an increase in total consumption over the next decade, with positive implications for the global economy and the environment (Floros, 2018). Other indicators that will increase natural gas consumption in terms of LNG in the future energy include: increase in proved 
global gas reserves; increase in LNG global trade; new and existing laws and regulations; increase in liquefaction plant capacity; and finally increase in LNG vessels (Newman, 2018).

\subsubsection{Increase in Proved Global Gas Reserves}

Gradual increase in the discovery of proved gas reserves is a major indication of LNG as the future energy source. Figure 6 shows global natural gas reserves from 2015 to 2017.

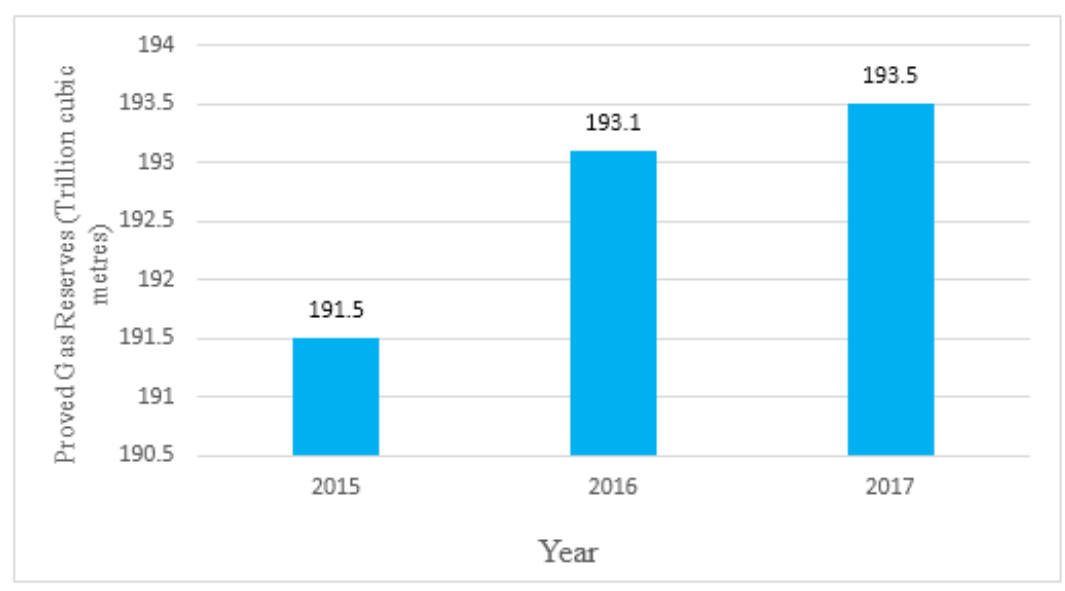

Figure6. Global Natural Gas Proved Reserves

From Figure 6, global natural gas proved reserves increased from 191.5 trillion cubic meters in 2015 to 193.1 trillion cubic meters and finally to 193.5 trillion cubic meters in 2016 and 2017 respectively. The increase in proved gas reserves is attributed to the development of new technologies to exploit reserves in remote areas. World natural gas consumption continues to grow and the world has large natural gas reserves, but much of them are located far from the gas markets and need huge investments in pipelines or LNG liquefaction plants to reach the final consumer. In addition, the extraction of natural gas to form LNG from unconventional sources such as shale gas, tight gas and coal bed methane especially in US is on the abrupt rise. The gas reserves are the largest energetic basin and using natural gas a worldwide energy source has increased in the past and will play a more important strategic role in the near future as shown by Figure 6 .

\subsubsection{Increase in LNG Global Trade}

According to the International Gas Union's (IGU) 2017 and 2018 World LNG Reports, LNG volume globally traded increased from 244.9 Million Tonnes (MT) by the end of 2015 to 258.0 MT by January 2017. That is a 13.1 MT increase over 2015. By March 2018, LNG globally traded volumes increased to 293.1 MT. Figure 7 shows global LNG traded volumes. The progressive increase in global LNG traded volumes was as a result of a corresponding increase in LNG supply driven by Australian and US projects and increasing global demand by Asia, most especially China (Carroll, 2018).

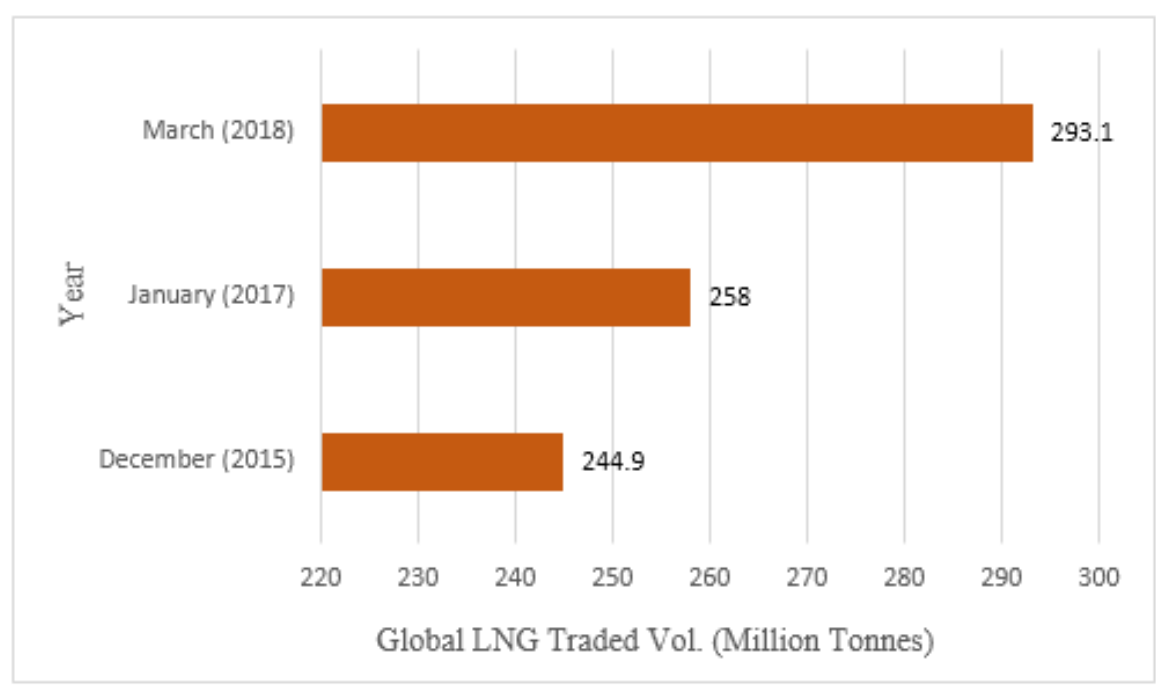

Figure7. Global LNG Traded Volume 


\subsubsection{Increase in Liquefaction Plants Capacity}

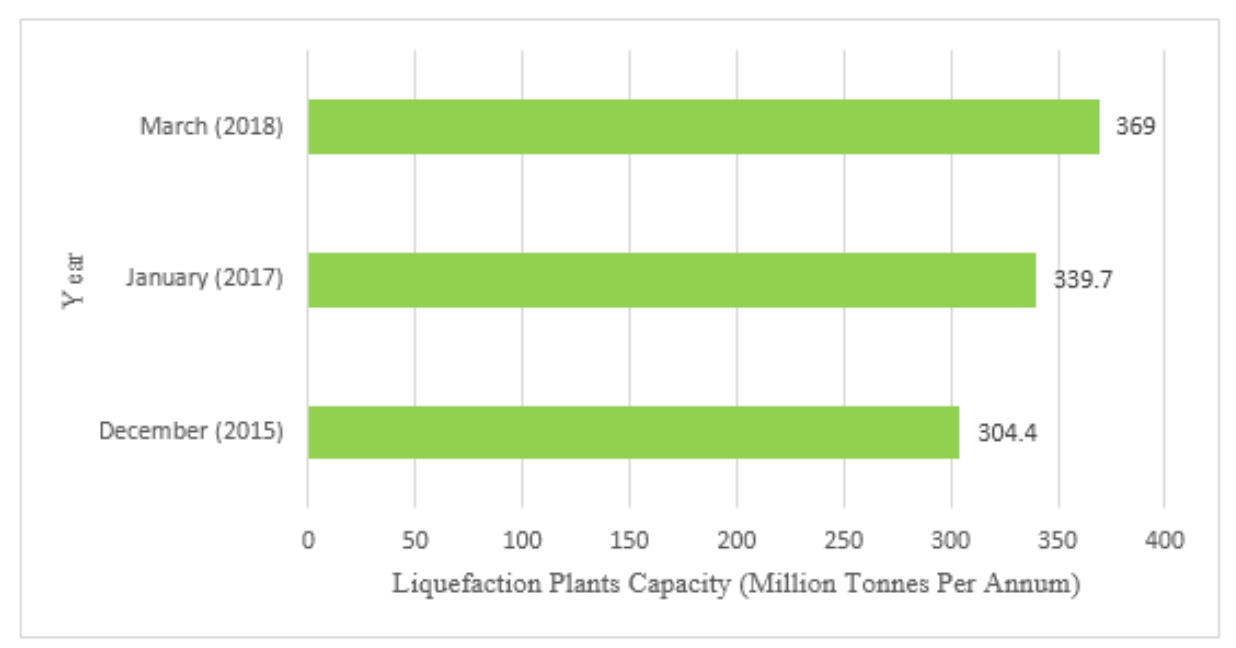

Figure8. Global Liquefaction Plants Capacity

Throughout the years, there has been a global increase in total liquefaction plants capacity as new proposed projects are executed, completed and operational for additional liquefaction processes. As shown in Figure 8, global nominal liquefaction capacity was 304.4 Million Tonnes per Annum (MTPA) at the end of 2015 and this increased to 339.7 MTPA by January 2017. The increase in liquefaction capacity during that period was due to four new projects totaling 31.7 MTPA of capacity which began commercial operations in 2016. As of March 2018, the total global liquefaction plant capacity had further increased to 369 MTPA and this was driven by operational plants in Australia and U.S. More proposed projects to add additional capacity to existing liquefaction plants are in progress and this shows that LNG is the future source of energy.

\subsubsection{New and Existing Laws and Regulations}

Currently, rules and regulations are put in place with the aim of achieving a clean, safe, reliable and environmentally friendly energy supply in the future. This in the long run affects the economy of individual countries in relation to their industrial sectors, electric power sectors as well as transportation sectors. Per regulations, natural gas which could be transported through pipelines or in a form of LNG is the best fit and fuel for the future (Newman, 2018). This is because natural gas is cheap and burns cleaner than other fossil fuels. China, for example, had made changes in its energy policy by adopting a proactive, cleaner and more efficient approach where natural gas is used to replace coal. China emits about 10 million tons of carbon dioxide $\left(\mathrm{CO}_{2}\right)$ per year and this pollutes the environment. Consequently, anti-pollution plans in the city of Beijing have been put in place, valued at more than $\$ 3$ billion to support renewable energy projects in real areas and control sources of pollution such as coal and road vehicles. Special $\mathrm{CO}_{2}$ emission limits have been imposed on industries, and because of this, China is responsible for approximately $15 \%$ of the global growth rate in gas consumption according to the 2018 BP statistical review. This is because of political efforts to transform coal-fired power plants into gas for the industrial and domestic sectors (Gil, 2018). This change in energy policy testifies that LNG is the energy source for the future.

Again, the International Marine Organisation (IMO) 2020 regulation has set more stringent global regulatory limits on sulfur in fuel oil used onboard ships to be $0.50 \%$ mass by mass for ships operating outside designated emission control areas against the current limit of $3.50 \%$, which has been in effect since January 1, 2012. The change is called IMO 2020 and it would be effective from January 1, 2020. The intent of the regulation is to provide environmental and health benefits for ports and nearby coastal areas by progressively decreasing emissions produced by heavy bunker fuels, referred to by the IMO as sulphur oxides and particulate matter (Atkinson and Welch, 2019). Compliance to this regulation will touch businesses of all sizes from oil refiners, shipping companies, LNG companies, crude oil producers and many more. According to Grati (2017), in order for ships to comply with the regulation, ships owners may have to purchase compliant bunker fuel or install scrubbers on-board to remove sulfur dioxide from the exhaust or make vessel modifications and switch to alternative fuel such as LNG bunkers. LNG bunkering, among the others, is the best choice for shippers to go for because purchasing compliant fuel of low sulphur, but more expensive fuel such as Marine Gas Oil (MGO) or installing 
scrubbers, are less favorable as compared to the use of LNG (Dalaklis et al., 2018). Moreover, LNG has already proven its value, since numerous ships are already running on this type of marine fuel. When LNG is used for propulsion, ships' emissions easily conform to the new regulatory requirements and less $\mathrm{CO}_{2}$ is released in the atmosphere. This is of positive contribution to dealing with the adverse overall effects of greenhouse gases.

\subsubsection{Increase in $L N G$ vessels}

According to International Gas Union (IGU) 2017 and 2018 world LNG report, there were about 439 LNG vessels including chartered Floating Storage Regasification Units (FSRUs) by the end of 2016 and this increased to 478 vessels including conventional vessels, Floating Storage Units (FSUs) and FSRUs at the end of 2017 (Carroll, 2018). This shows how the shipping market is continuously constructing more vessels with different modifications for LNG companies to efficiently exploit the proved gas reserves. Figure 9 shows the global number of LNG vessels.

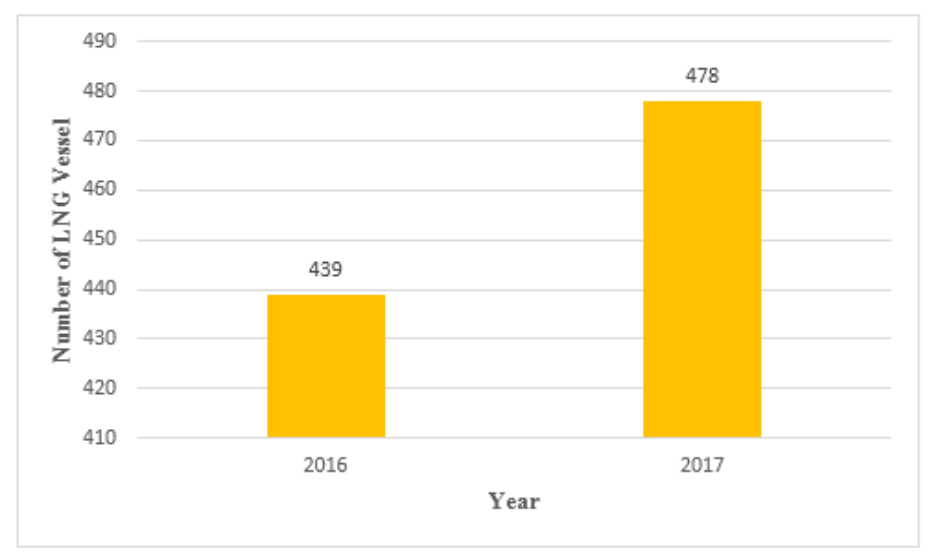

Figure9. Global Number of LNG Vessels

\subsection{Challenges Associated with LNG}

Natural gas emits about 50 to 60 percent less carbon dioxide than coal and petroleum when combusted, and as such, is considered as a clean energy source. Studies show that the future demand for energy is going to shift towards clean energy; most of petroleum energy products are not clean and will eventually fall out simply because most of them do not measure up to the crucial requirements for a reliable energy supply (Kho, 2005). Looking at the environmental significance presented by its liquefaction, LNG stands out to be the energy source for the future. However, it is also accompanied with several challenges such as:

- Project and equity financing challenges especially with LNG FSRU;

- Delay in FSRU projects due to permitting, approval and fiscal regimes;

- Challenging weather conditions in surrounding environments for LNG - related projects could lead to project cancellation; and

- The ability of a fuel to burn directly in an engine presents a fundamental challenge for LNG since it cannot be burnt directly in an engine. World rising demand for energy can be greatly increased by the potential of technology. This is only made possible by the development of an LNG engine which can directly burn the LNG within. Hence, LNG can then compete efficiently with oil (Bowen et al., 2018).

\section{CONCLUSION}

There are a number of factors that drive petroleum energy as well as indicators that make LNG the future energy source together with its challenges. From review of literature and information obtained from several sources including BP statistics, EIA, Statista and IGU, the following conclusions were drawn:

- LNG is a clean, safe and environmentally friendly energy source hence, a preferred choice of energy source for the future. This is because liquefaction of natural gas tends to remove impurities and other contaminants like $\mathrm{CO}_{2}$ and nitrous oxide which are not safe and unclean. Thus, impurities causing global warming and environmental pollution are mostly eliminated. 
- The drivers of petroleum identified were population growth, electrical power and transportation. These factors place a high demand on petroleum energy from the past, through the present and into the future as each factor continuously increases year after the other.

- Increase in proved gas reserves, LNG global trade, liquefaction plant capacity, LNG vessels and enforcement of new and existing regulations were some of the indicators identified to make LNG the future energy source.

- Delay in approval, permitting and fiscal regimes of LNG projects, equity and project financing challenges, challenging weather conditions and the fact that LNG cannot be burnt directly in an engine are some of the challenges LNG is faced with.

\section{ACKNOWLEDGEMENT}

The authors wish to express their appreciation to the University of Mines and Technology, Tarkwa for their support.

\section{REFERENCES}

[1] Anon. (2018a), BP Statistical Review of World Energy 2018, 67th ed., BP Publication, London, UK, 56 pp.

[2] Anon. (2018b), Distribution of Transportation Energy Consumption by Source, 2018 Review, U.S. Energy Information Administration (EIA) Publication, Washington, USA, 1 pp.

[3] Atkinson, K. and Welch, S. (2019), "IMO 2020 Regulation: Standards, Compliance and Outlook for Marine Fuels", https://ihsmarkit.com/topic/imo-2020-regulation.html Accessed: March 15, 2019.

[4] Bowen, R. R., Miller, M. R., Planteen, J. L., Tredennick, O. W., Norman, G. M., Duke, C. M. and Greer, M. N. (2018), "LNG Technology Advances and Challenges", International Petroleum Conference, Kuala Lumpur, Malaysia, 9 pp.

[5] Carroll, D. (2018), 2018 World LNG Report, 27th ed., International Gas Union Publications, Barcelona, Spain, pp. $4-15$.

[6] Dalaklis, D., Olcer, A., Balini, F. and Dewitz, L. J. (2018), Protecting the Arctic Environment: Challenges and Opportunities for Liquefied Natural Gas, Hal Archives-Ouvertes Publication, France, pp. $468-469$.

[7] Denchak, M. (2018), "Fossil Fuels: The Dirty Facts", https://www.nrdc.org/stories/fossil-fuels-dirty-facts Accessed: January 15, 2019.

[8] Floros, D. (2018), "Energy: The Revenge of Blue Gold (Natural Gas)", https://www.eniday.com/en/education_en/natural-gas-energy-mix/. Accessed: March 2, 2019.

[9] Gil, A. (2018), "The Change in Energy Policy in China, Gas for Coal", https://www.magnuscmd.com/thechange-in-energy-policy-in-china-gas-for-coal/ Accessed: March 15, 2019.

[10] Grati, H. (2017), "Bunker Fuel in 2020", https://ihsmarkit.com/research-analysis/imo/bunker-fuel-in2020.html. Accessed: March 2, 2019.

[11] Kho, Y. (2005), "LNG Terminal Technology”, International Offshore and Polar Engineering Conference, Seoul, Korea, 6 pp.

[12] Kinder, C. (1998), "The Population Explosion: Causes and Consequences", Yale-New Haven Teachers Institute, Vol. 7, No. 2, pp. $1-3$.

[13] Newman, N. (2018), “The Fuel of The Future Is Gas”, https://www.eniday.com/en/ technology_en/fuel-offuture-is-gas/. Accessed: March 2, 2019.

[14] Rodrigue, J. P. (2017), "Transportation and Energy", https://transportgeography.org/?page_id=5717 Accessed: March 2, 2019.

[15] Sokolov, D., Apokin, A., Hamdani, S., Hussein, M. and Razavi, S. M. (2017), “2017 Global Gas Outlook”, Gas Exporting Countries Forum, WestBay, Doha-Qatar, pp. 1 - 4.

[16] Song, M., Wu, N. and Kaiya, W. (2014), "Energy Consumption and Energy Efficiency of the Transportation Sector in Shanghai", Sustainability 2014 Journal, Vol. 6, No. 702, pp. $703-704$.

Citation: E.M. Amarfio, et.al, "The Future and Challenges of LNG", International Journal of Petroleum and Petrochemical Engineering, 6(3), pp. 21-28. DOI: https:// doi.org/10.20431/2454-7980.0603003

Copyright: () 2020 Authors, this is an open-access article distributed under the terms of the Creative Commons Attribution License, which permits unrestricted use, distribution, and reproduction in any medium, provided the original author and source are credited. 